\title{
Article \\ Policy Design and Non-Design: Towards a Spectrum of Policy Formulation Types
}

\author{
Michael Howlett ${ }^{1,2, *}$ and Ishani Mukherjee ${ }^{2}$ \\ ${ }^{1}$ Department of Political Science, Simon Fraser University, Burnaby, BC, Canada; E-Mail: howlett@sfu.ca; \\ Tel.:+1-778-782-3082 Fax: +1-778-782-4293 \\ ${ }^{2}$ Lee Kuan Yew School of Public Policy, National University of Singapore, Singapore; E-Mail: ishani@nus.edu.sg \\ * Corresponding author
}

Submitted: 29 July 2014 | In Revised Form: 1 October 2014| Accepted: 6 October 2014 | Published: 13 November 2014

\begin{abstract}
Public policies are the result of efforts made by governments to alter aspects of behaviour-both that of their own agents and of society at large-in order to carry out some end or purpose. They are comprised of arrangements of policy goals and policy means matched through some decision-making process. These policy-making efforts can be more, or less, systematic in attempting to match ends and means in a logical fashion or can result from much less systematic processes. "Policy design" implies a knowledge-based process in which the choice of means or mechanisms through which policy goals are given effect follows a logical process of inference from known or learned relationships between means and outcomes. This includes both design in which means are selected in accordance with experience and knowledge and that in which principles and relationships are incorrectly or only partially articulated or understood. Policy decisions can be careful and deliberate in attempting to best resolve a problem or can be highly contingent and driven by situational logics. Decisions stemming from bargaining or opportunism can also be distinguished from those which result from careful analysis and assessment. This article considers both modes and formulates a spectrum of policy formulation types between "design" and "non-design" which helps clarify the nature of each type and the likelihood of each unfolding.
\end{abstract}

\section{Keywords}

non-design; policy design; public policy

\section{Issue}

This article is part of a regular issue of Politics and Governance, edited by Professor Andrej J. Zwitter (University of Groningen, The Netherlands) and Professor Amelia Hadfield (Canterbury Christ Church University, UK).

(C) 2014 by the authors; licensee Cogitatio (Lisbon, Portugal). This article is licensed under a Creative Commons Attribution 4.0 International License (CC BY).

\section{Introduction: Policy Design Studies Past and Future}

A roadmap for a new "policy design orientation" exists in studies undertaken in recent years into the formulation of complex policy mixes in fields such as energy and environmental policy, among others (Howlett, 2014a; 2014b; Howlett \& Lejano, 2013; Howlett, Mukherjee, \& Woo, 2014). This new design orientation focuses attention on the construction of policy packages operating in complex multi-policy and multi-level design contexts which are expected to address multiple goals and ob- jectives (del Rio \& Howlett, 2013). It seeks to better describe the nature of the bundles or portfolios of tools which can be used to address policy problems and to help understand the interactive effects which occur when multiple tools are used over time (Doremus, 2003; Howlett, 2014b; Howlett, Mukherjee, \& Woo, 2014; Jordan, Benson, Wurzel, \& Zito, 2011; Jordan, Benson, Zito, \& Wurzel, 2012; Yi \& Feiock, 2012).

The research agenda of this new design orientation is focused on questions which an earlier literature on the subject largely neglected, such as the trade-offs ex- 
isting between different tools in complex policy mixes and how to deal with the synergies and conflicts which result from tool interactions; as well as the different means and patterns - such as layering - through which policy mixes evolve over time (Tan, Migone, Wellstead, \& Evans, 2014; Thelen, 2004).

This temporal orientation highlights the processes through which policies emerge and raises the issues of how to distinguish between design and other formulation and decision-making processes and the frequency or likelihood of occurrence of each. Many formulation situations, for example, involve information and knowledge limits or imultiple actors whose relationships may be more adversarial or competitive than is typically associated with a "design" process and outcome (Gero, 1990; Schön, 1988). That is, not all policymaking is logic or knowledge driven and it is debatable how closely policy-makers approximate the instrumental reasoning which is generally thought to characterize this field (Howlett et al., 2009).

This paper addresses the differences between more, and less, analytical and instrumental policy formulation and decision processes and the likelihood of each occurring. By engaging in a discussion of the intention to engage in policy design-whether towards public interest or more politically driven opportunism - and of the capacity of governments to undertake such design efforts, the paper develops a continuum of several formulation processes that can exist between ideal instrumental and problem-solution driven policy design and other more contingent and less intentional processes.

\section{What Is Policy Design?}

Within the policy sciences, "design" has been linked both to policy instruments and implementation (May, 2003) and to the impact of policy ideas and advice on policy formulation (Linder \& Peters, 1990a). It is usually thought to involve the deliberate and conscious attempt to define policy goals and connect them in an instrumental fashion to instruments or tools expected to realize those objectives (Gilabert \& Lawford-Smith, 2012; Majone, 1975; May, 2003). Policy design, in this sense, is a specific form of policy formulation based on the gathering of knowledge about the effects of policy tool use on policy targets and the application of that knowledge to the development and implementation of policies aimed at the attainment of specifically desired public policy outcomes and ambitions (Bobrow, 2006; Bobrow \& Dryzek, 1987; Montpetit, 2003; Weaver, 2009, 2010).

In this sense, policy designs can be seen to contain both a substantive component-a set of alternative arrangements thought potentially capable of resolving or addressing some aspect of a policy problem, one or more of which is ultimately put into practice-as well as a procedural component-a set of activities related to securing some level of agreement among those charged with formulating, deciding upon, and administering that alternative vis-à-vis other alternatives (Howlett, 2011). Design thus overlaps and straddles both policy formulation, decision-making and policy implementation and involves actors, ideas and interests active at each of these stages of the policy process (Howlett, Ramesh, \& Perl, 2009). However it also posits a very specific form of interaction among these elements, driven by knowledge and evidence of alternatives' merits and demerits in achieving policy goals rather than by other processes such as bargaining or electioneering among key policy actors.

Conceptually, a policy design process begins with the analysis of the abilities of different kinds of policy tools to affect policy outputs and outcomes and the kinds of resources required to allow them to operate as intended (Hood, 1986; Salamon, 2002). This instrumental knowledge is contextual in the sense that it requires a special understanding of how the use of specific kinds of instruments affects target group behaviour and compliance with government aims. It thus includes knowledge and consideration of many constraints on tool use originating in the limits of existing knowledge, prevailing governance structures, and other arrangements and behaviours which may preclude consideration of certain options and promote others (Howlett, 2009a, 2011). It requires both government analytical and evidentiary capacity as well as the intention to exercise it.

Such a means-ends understanding of policy-making permeates the policy design orientation but, of course, is only one possible orientation or set of practices which can be followed in policy formulation and result in policy-outputs (Colebatch, 1998; Tribe, 1972). In the design case, policy formulators are expected as much as possible to base their analyses on logic, knowledge and experience rather than, for example, purely political calculations and forms of satisficing behaviour which also can serve to generate alternatives (Bendor, Kumar, \& Siegel, 2009; Sidney, 2007).

Policy design studies, of course, acknowledge that not all policy work is rational in this instrumental sense and often deals with alternative forms of policy formulation by separating out two dimensions of the design experience: on the one hand the exploration of the procedural aspects of design-the specific types of policy formulation activities which lead to design rather than some other form of policy generation-and on the other the substantive components - that is, the substance or content of a design in terms of the instruments and instrument settings of which it is composed. This is the policy-relevant articulation of the well-known distinction in design studies generally between "design-as-verb" ("policy formulation") and "design-as-noun" (policy tool and instrument combinations). ${ }^{1}$

\footnotetext{
1 This is similar to the general orientation towards design found in other fields such as architecture, urban planning or
} 
The idea is that even when policy processes are less rational or information-driven and more political or interest-driven, the design of a policy, conceptually at least, can be divorced from the processes involved in its enactment. Thus regardless of the nature of the actual alternative formulation process which exists in a specific context, it is still possible to imagine a more instrumental world and hence consider or promote design alternatives "in-themselves" as ideal-type artifacts. These can then be developed and studied in preparation for decision-making circumstances which might be propitious to their adoption either in "pure" form or with some minor adjustments or amendments. This is the bread-and-butter of policy analytical work undertaken by think tanks, policy institutes and policy schools which generally criticize existing arrangements and propose more "rational" alternatives; that is, new or revised solutions to old or redefined problems felt more likely to achieve their goals in theory and practice or to do so more effectively.

Again, however, this does not preclude, but rather is built upon the recognition and acceptance of the fact that in some policy decisions and formulation processes "design" considerations may be more or less absent and the quality of the logical or empirical relations between policy components as solutions to problems may be incorrect or ignored (Cohen, March, \& Olsen, 1979; Dryzek, 1983; Eijlander, 2005; Franchino \& Hoyland, 2009; Kingdon, 1984; Sager \& Rielle, 2013). This includes a variety of contexts in which formulators or decision-makers, for example, may engage in interestdriven trade-offs or log-rolling between different values or resource uses or, more extremely, might engage in venal or corrupt behaviour in which personal gain from a decision may trump other evaluative criteria.

These "non-design" situations are well known in political science but have not been well studied in the policy sciences and the extent to which such considerations as political gain or blame avoidance calculations outweigh instrumental factors in policy formulation is a key question (Hood, 2010). As Junginger (2013) recently argued, at the present time we continue to know too little about many important aspects of design work, especially about the nature of the kinds of policy formulation activities which bring about either a design or a non-design process. As she put it, we know very little about "the actual activities of designing that bring policies into being - of how people involved in the creation of policies go about identifying design problems and design criteria, about the methods they employ in their design process" (p. 3). This highlights the continued need to distinguish more carefully between design and non-design processes and to better understand the mechanics of policy formulation involved in developing

industrial design. See Hillier, Musgrove and O'Sullivan (1972), Hillier and Leaman (1974), and Gero (1990). policy alternatives (Linder \& Peters, 1988; Wintges, 2007).

\section{What Is Policy Design?}

In contrast to those who view policy-making as intentional and instrumentally rational, many commentators, pundits and jaded or more cynical members of the public assume that all policy-making, as the output of a political system and decision-making process, is inherently interest-driven, ideological and hence irrational in a design sense. However policy scholars have noted many instances in which processes of policy formulation and decision-making are governed less by considerations of self-interest, interest accommodation, bargaining or ideology than by concerns about criteria such as the practical efficiency and effectiveness of policy alternatives. These latter efforts involve policy actors in the process of thinking more systematically and analytically about the merits and demerits of policy options and alternatives from a functional or instrumental perspective (Bobrow, 2006; Bobrow \& Dryzek, 1987).

Studies of policy design with this general instrumental orientation towards policy formulation began at the very origins of the policy sciences when many pivotal early works contained within them the idea of improving policy outcomes through more systematic application of knowledge to policy formulation activities (Lasswell \& Lerner, 1951; May, 2003; Wildavsky, 1979). ${ }^{2}$ In his foundational work on the policy sciences, for example, Harold Lasswell argued for the separation of the processes of policy formulation from decisionmaking and implementation, highlighting the centrality and significance of policy instruments and instrument choices made in the formulation process for policy outcomes and arguing for the need to bring interdisciplinary knowledge to bear on the development of the appropriate means to resolve public problems and issues (Lasswell, 1954).

For the "old" policy design studies which emerged from this foundational work, the historical and institutional context of policy-making was seen to bear significant weight in policy formulation, and this was often argued to be determinant of both the content and activities of designs and designing (Clemens \& Cook, 1999). In this view, as policy contexts and conditions changed and evolved, so too did the set of policy means or alternatives which were deemed acceptable

\footnotetext{
2 Policy design studies have been undertaken since at least the 1950s (Dahl \& Lindblom, 1953; Kirschen et al., 1964; Tinbergen, 1952). Most of the early studies focused on policy tools and had a strong focus on policy implementation issues and processes; paying much less attention to policy development or formulation issues which are the hallmark of current studies with a design orientation (Hood, 1986; Hood \& Margetts, 2007).
} 
or feasible by an evolving set of policy actors involved in policy-making, themselves informed by shifting ideas and calculations of the appropriateness of a particular design and its consequences (Goldmann, 2005; Majone, 1975, 1976; March \& Olsen, 2004; Howlett, 2011). While this context might contain irrational elements such as ideological or partisan pre-dispositions towards certain kinds of instruments-such as a general pro-market orientation among the public or elites-the choice of tool within this context remained an intentional, rational act.

This highly contextual orientation in early policy studies (Torgerson, 1985, 1990) led some policy scholars in the 1970s to argue policy decisions were by nature the result of processes so highly contingent and fraught with uncertainty that decision-making would invariably be informed more by the opportunistic behaviour of decision-makers within fluid policy-making contexts than by careful deliberation and "design" thinking about the logical or functional merits and demerits of specific alternative arrangements of policy goals and means (Cohen et al., 1979; Dryzek, 1983; Kingdon, 1984; Lindblom, 1959). ${ }^{3}$ This led some to express serious doubts that policy could truly be "designed" in the way that proponents of a more instrumental policy design orientation advocated (deLeon, 1988; Dryzek \& Ripley, 1988).

Many other scholars, however, questioned the extent of this emphasis on contextuality and contingency (Dror, 1964). The academic enquiry of policy designthat is, self-consciously dealing with both policy processes and substance under a knowledge-driven, instrumental rubric-emerged and flourished throughout the 1970s and 1980s in trying to clarify what a design process involved and when it was likely to occur (see for example, Salamon 1981, 1989, 2002). In a series of path-breaking articles in the 1980s and early 1990s authors such as Linder and Peters (1984, 1988, 1990a, 1990b, 1990c, 1990d, 1991) sought to re-orient policy studies in a design direction by arguing that the process of policy designing as a type of formulation activity was conceptually distinct from a policy design itself, in the same way that an analytical distinction can be made between the development of an abstract concept or plan in architecture and the manifestation of that conception through engineering and construction practices followed on the ground (Schön, 1988, 1992).

Incorporating this distinction between design-asformulation-process and design-as-policy-content, design studies in the 1980s shifted back from the study of "designing" to the study of "designs" themselves, with a specific focus on better understanding how individual implementation-related policy tools and instruments such as taxes and subsidies or regulation and public

${ }^{3}$ Of course this is a view some continue to hold. See for example Eijlander (2005), Franchino and Hoyland (2009). ownership operated in theory and practice (Mayntz, 1979; Sterner, 2003; Woodside, 1986). ${ }^{4}$

By the early 1980s, this tools literature had merged with the policy design orientation and emerged as a body of policy design literature in its own right. Students of policy design consequently embarked upon theory building, developing more and better typologies of policy instruments that sought to aid the conceptualization of these instruments and their similarities and differences, and attempting to provide a greater understanding of the motivations and reasons underlying their use (Bressers \& Honigh, 1986; Bressers \& Klok, 1988; Hood, 1986; Salamon, 1981; Trebilcock \& Hartle, 1982; Tupper \& Doern, 1981). Other scholarly work during this period continued to further elucidate the nature and use of specific policy tools, especially tools such as "command-and-control" regulations and financial inducements such as tax incentives but also many others (Hood, 1986; Howlett, 1991; Landry, Varone, \& Goggin, 1998; Tupper \& Doern, 1981; Vedung, Bemelmans-Videc, \& Rist, 1997).

This tools orientation sparked interest in a range of related subjects, such as the study of target group behaviour, of implementation failures and their role in policy success, and of the linkages connecting the two; with policy scholars turning their attention to the description and classification of alternative implementation instruments and the factors which conditioned their effective use and deployment (Goggin, Bowman, Lester, \& O'Toole, 1990; Mayntz, 1979; O'Toole, 2000; Schneider \& Ingram, 1990a, 1990b, 1994). These works provided a deeper understanding of the social and behavioural factors underpinning the use of specific kinds of policy designs in practice. ${ }^{5}$ In general it was believed

\footnotetext{
${ }^{4}$ Students of public policy making were joined in this effort by scholars of economics and law who studied the evaluation of policy outputs in terms of their impacts on outcomes as well as the role of law and legislation in effecting policy tool choices and designs (Bobrow \& Dryzek, 1987; Keyes, 1996; Stokey \& Zeckhauser, 1978). And studies in management and administration at the time also sought to explore the linkages between politics, administration and implementation in the effort to better understand policy tool choices and patterns of use (Trebilcock \& Hartle, 1982). Researchers also looked at how policy instrument choices tended to shift over time (Lowi, 1966, 1972, 1985), examples of which during this period included the rise of privatization and deregulation (Howlett \& Ramesh, 1993) and the first wave of governance thinking advocating the use of network management or nongovernmental tools (Peters \& Pierre, 1998).

${ }^{5}$ Subsequent contributions would further advance the study of the behavioural aspects of the design process and raised the issue of the difference between design and non-design to the fore (Hood, 2007; Ingram \& Schneider, 1990a; Mondou \& Montpetit, 2010; Schneider \& Ingram, 1997; Timmermans, Rothmayr, Serduelt, \&Varone, 1998). At this time, for example, Bardach (1980) and Salamon (1981) went so far as to argue that the definition of policy in terms of "issues" or "prob-
} 
a greater understanding of implementation instruments and the factors underlying instrument choice would benefit policy design both as a practice and a theoretical body of knowledge, contributing to more positive policy outcomes (Linder \& Peters, 1984; Mayntz, 1979; Woodside, 1986). Studies on pollution prevention and professional regulation conducted at the time, for example, benefited from advances in the systematic study of policy instruments which influenced the design and creation of new alternative instruments in these and other fields (Hippes, 1988; Trebilcock \& Prichard, 1983).

Most of this work focused on implementation and tool design-as-a-noun, however, and ignored or failed to examine in detail the issues involved in policydesign-as-formulation-process. ${ }^{6}$ Understanding the difference between "non-design" and design processes thus remains very much a part of the outstanding research agenda in contemporary policy design studies. As shall be argued below, however, some progress in this area can be made by illustrating these different formulation processes as a continuum ranging from intentional ones informed by an instrumental logic of best matching public policy goals and means ("design"), to those that are more contingent and more susceptible to purely interest-driven or political motivations and logics ("non-design").

\subsection{Modeling Non-Design: Revisiting the Pre-Conditions of Policy Design}

The design end of the spectrum has already been discussed. With respect to non-design, it bears repeating that the modern policy studies movement did begin with the recognition that public policy-making results from the interactions of policy-makers in the exercise

lems" originally made by scholars at the outset of the policy studies movement (Mintrom, 2007) was misguided and that policy should instead have been defined from the start in terms of the "instruments" used in policy-making. They advocated shifting the focus of policy studies squarely towards the study of the design and operation of such tools, later defined to include both traditional "substantive" tools such as regulation and public ownership and more "procedural" ones such as the use of advisory commissions and public participation exercises (Howlett, 2000).

${ }^{6}$ Of course, not all work on policy instruments has restricted itself to implementation issues. Work on the exploration of "instrumentation" for example, has considered larger issues about feedback processes from instrument choices to the politics of policy formation, as has some work on instruments and network governance (see de Bruijn \& ten Heuvelhof, 1997; Lascoumes \& Le Gales, 2007). However these can still be distinguished from the new design studies, given the latter's almost exclusive emphasis on formulation and its resulting concern for understanding the inherent nuances involved in developing mechanisms for meeting policy goals, couched within contextual realities, which the former studies still lack. of power, legitimate or otherwise (Arts \& van Tatenhove, 2004; Lasswell, 1958; Stone, 1988). Although some of these efforts were noted to be arbitrary or capricious, most were viewed as representing the concerted efforts of governments to intentionally act in an instrumental way; that is, to attempt to achieve a particular policy goal or end through the use of a relatively well known set of policy means developed over many years of state-building experience (Lasswell \& Lerner, 1951). As discussed above, it was acknowledged the goals pursued were wide-ranging and often posed no small amount of difficulty and complexity in both their definition and diagnosis, with the implication that the formulation of solutions likely to succeed in addressing them necessitated the systematic consideration of the impact and feasibility of the use of specific kinds of policy means or instruments as well as a clear understanding of the contexts of their use (Parsons, 1995, 2001).

This work thus depicted instrumental policy-making as a specific kind of policy activity which occurred in specific circumstances in which knowledge of the general impact of specific policy tools was combined with the practical capacity of governments to identify and implement suitable technical means in the effort to achieve a specific policy aim. This activity was expected to occur ex ante and independently of other considerations such as political or personal gain which might also affect decision-making and implementation processes but which should be removed from the deliberations of formulation.

Significantly for considerations of design and nondesign processes, as noted above, this "design" activity was recognized as being inherently context bound, that is, requiring a situation where there was support for knowledge-based policy analysis on the part of policymakers and where the demand for such analysis was met by a ready supply (Howlett et al., 2014). Favorable design circumstances hence required not only the presence of high quality information on the range and impacts of policy alternatives but also the presence of a high level of technical capacity and expertise on the part of policy analysts if knowledge was to be mobilized effectively so that policy instruments were effectively and efficiently matched to policy goals and targets (Dunlop, 2009; Howlett, 2009a, 2010; Howlett \& Rayner, 2014; Radaelli \& Dunlop, 2013). Secondly, it was also recognized that not only "spatial" but also "temporal" aspects of policy formulation contexts such as policy legacies or prior commitments on the part of policy-makers limited consideration of alternatives. Where there was a relatively high policy "lock-in" on existing tool arrangements, this could preclude consideration or adoption of potentially superior alternatives (Howlett \& Rayner, 2013).

When propitious conditions were present, however, purposive design activity resulting in good alterna- 
tive generation and assessment was thought to be possible, much as is expected in the current era with recent efforts at improving knowledge mobilization in policy-making in the form of an emphasis upon enhanced "evidence-based policy-making" (Bhatta, 2002; Locke, 2009; Nutley, Walter, \& Davies, 2007). When conditions are not ripe, however, either poor designs would ensue from incomplete knowledge and information even with the best government intent, or less technical and more overtly political forms of policymaking would be more likely to ensue (Davies, 2004; Howlett, 2009b; Moseley \& Tierney, 2004). The fervent wish of proponents of design orientation is generally to reduce instances of poor and non-design to as few as possible by promoting the kinds of orientations and dedication of resources required for better design processes to occur. This, is expected to result in policies more likely to solve pressing problems, correct social ills and better serve the public good through the improved mobilization of knowledge in the service of policy (Azuela \& Barroso, 2012; Bobrow, 2006; Wildavsky, 1979).

Table 1 presents a schematic illustrating how these two different aspects of policy-making-a design intention and the capacity to carry it out-create different policy formulation spaces which enable very different policy design processes. This sets out a set of formulation processes lying between the intention and ability to undertake purposive, instrumental policy design and the intention to meet more political goals coupled with the presence of significant policy resource constraints or tool lock-in affects.

As this table shows, both policy and political formulation processes can be capable or poor depending on the context of policy-making and the intention of government in enacting policy. This suggests that a spectrum of design and non-design formulation processes exists between capable policy processes informed by instrumental motivations and "poor" political ones driven by other logics but also unlikely to attain them. In between the poles lie other spaces and formulation types such as poor design and capable non-design, alternatives often mooted but rarely examined in the policy sciences.

\section{Developing a Spectrum of Design and Non-Design Activities: The Significance of Layering and Temporality}

While the distinction between policy-driven and politically-driven processes is clear, in order to be more precise about variations within these general types and their frequency of occurrence, it is necessary to examine in more detail the nature of the constraints on government intentions which can result in poor outcomes.

As set out above, one key factor is the extent to which an existing policy regime is settled in place. That is, very few design processes begin de novo. Examples of new policy "packages" in many areas, from welfare policy to natural resource ones exist only historically, reflecting times before which there was no previous history of a policy response to a perceived policy problem. For example, the United States (US) Clean Air Act (CAA) (first enacted in 1970) was the first major federal air pollution legislation in the US that established the very first national benchmark for ambient sulfur dioxide $\left(\mathrm{SO}_{2}\right)$ (Libecap, 2005; Schmalensee, Joskow, Ellerman, Montero, \& Bailey, 1998).

Such examples of new policy designs are understandably few. Most policy initiatives rather deal with already created policies that are limited by historical legacies, and can be hampered due to internal inconsistencies which reforms and revisions (re-designs) attempt to address and correct. In this case legacies from earlier rounds of decision-making affect the introduction of new elements which may conflict with preexisting policy components. Although other policy instrument groupings could theoretically be more successful in creating an internally supportive combination (Grabosky, 1994; Gunningham, Grabosky, \& Sinclair, 1998; Hou \& Brewer, 2010; Howlett, 2004; Howlett \& Rayner, 2007; del Rio, 2010; Barnett \& Shore, 2009; Blonz, Vajjhala, \& Safirova, 2008; Buckman \& Diesendorf, 2010; Roch, Pitts, \& Navarro, 2010) it may be very difficult to accomplish or even propose such changes, and designs instead often focus on reform rather than replacement of an existing arrangement.

Table 1. Types of policy formulation spaces: Situating design and non-design processes.

\begin{tabular}{|c|c|c|c|}
\hline & \multicolumn{3}{|c|}{ Level of Government Knowledge and Other Resources } \\
\hline \multirow{5}{*}{$\begin{array}{l}\text { Government } \\
\text { Formulation } \\
\text { Intention }\end{array}$} & \multirow{3}{*}{ More Instrumental } & High & Low \\
\hline & & Capable Policy Design Space & Poor Policy Design Space \\
\hline & & $\begin{array}{l}\text { Relatively unconstrained formulation via } \\
\text { desian is possible }\end{array}$ & $\begin{array}{l}\text { Only partially informed or restricted design } \\
\text { is possible }\end{array}$ \\
\hline & Less Instrumental & Capable Political Non-Design Space & Poor Political Non-Design Space \\
\hline & & $\begin{array}{l}\text { Relatively unconstrained non-design } \\
\text { processes are possible }\end{array}$ & Only poorly informed non-design is possible \\
\hline
\end{tabular}


Policy development strongly marked by layering in this way is typically one where new elements are added to the policy mix without the removal of older ones and existing elements are stretched to try to fit new goals and changing circumstances (van der Heijden, 2011). ${ }^{7}$ That is, policy arrangements are often the result of transformation pathways that can easily lead to internal contradictions emerging between tools and goals within policy mixes (Hacker, 2004), and mixes of policy elements can emerge over long stretches of time as a result of successive policy decisions which are not necessarily congruent. An example of such incongruence within a policy mix can be found in the CAA, the development of which has been heavily analyzed since the 1970s (Ackerman, 1981; Greenstone, 2001; among others). The 1977 amendments to the Act created a "new source bias" as all new coal-powered plants were required to install scrubbers even if they used lowsulfur coal. This rule undermined the comparative advantage of "cleaner" coal as the amendments raised the cost of shifting to new, less polluting plants and extended the economic lives of older, more polluting plants that did not have to shoulder the added cost of scrubbers (Libecap, 2005).

This is only one small example of a general situation where the initial logic of each decision matching policy tool and target may have been clear, but through multiple layering processes they can gradually transform over time into incongruent mixes (Bode, 2006; Hacker, 2004; Howlett \& Rayner, 1995; Orren \& Skowronek, 1998; Rayner, Howlett, Wilson, Cashore, \& Hoberg, 2001; Torenvlied \& Akkerman, 2004; van der Heijden, 2011). This can create policy portfolios or mixes that contain various incompatibilities, tending to frustrate the achievement of policy goals.

The contextual "lock in" that leads to layering impacts the formulation process by restricting a government's ability to evaluate alternatives and plan or design in a purely optimal instrumental manner (Howlett, 2009a; Oliphant \& Howlett, 2010; Williams, 2012). Layering typically results in processes of (re)design which alters only some aspects of a pre-existing arrangement and can thus be distinguished from processes of new policy packaging or complete replacement. Distinguishing between different types of layering allows us to further separate and identify different kinds of design and non-design processes from each other.

\footnotetext{
7 Layering, of course is a concept developed in the neoinstitutional sociological literature by some of its leading figures, namely Beland (2007), Beland and Hacker (2004), Hacker (2004), Stead and Meijers (2004) and Thelen (2004) to explain the pattern through which social and political institutions have evolved over long-periods of time. As applied to policy-making, "layering" connotes a process in which new elements are simply added to an existing regime often without abandoning previous ones so that polices accrete in a palimpsest-like fashion (Carter, 2012).
}

While earlier work on design processes tended to suggest that design would always occur in spaces where policy packages could be designed "en bloc", it is now recognized that most design circumstances involve building on the foundations created in another era, working within already sub-optimal design spaces (Howlett \& Rayner, 2013). Optimizing the choice of instruments when a pre-existing mix exists thus requires an additional level of knowledge of instrument-goal interactions and usually leads to design through "patching" rather than "packaging" (Howlett \& Rayner, 2013). That is, in situations with significant policy legacies, designers often attempt to "patch" or restructure existing policy elements rather than propose completely new alternative arrangements even if the situation might require the latter for the sake of optimally enhancing coherence and consistency in the reformed policy mix (Eliadis, Hill, \& Howlett, 2005; Howlett \& Rayner, 2013; Gunningham \& Sinclair, 1999a, 1999b; Thelen, 2004; Thelen et al., 2003). Hence even where the intention to systematically design may be high it may only be partial in the sense that only patching and not replacement is on the table.

A key first distinction among design formulation processes thus concerns whether they involve "packaging" a new policy mix or "patching" an old one. Policy design scholars are very interested in the processes through which policy formulators, like software designers, can issue such "patches" to correct flaws in existing mixes or allow them to adapt to changing circumstances (Howlett, 2013; Howlett \& Rayner, 2013; Rayner, 2013). ${ }^{8}$ Such patching or "smart layering" has often been thought to be inherently sub-optimal but patching in itself should be seen not as "non-design", but rather as constrained (re)design as a new layer is formulated in an effort to overcome anomalies or problems existing with earlier arrangements (Howlett \& Rayner, 2013).

Patching can be done well if governments possess the capacity to do so but can also be done poorly if they do not. An example of poor patching is policy "stretching" (Feindt \& Flynn, 2009). This is where, operating over periods of decades or more, elements of a mix are simply extended to cover areas they were not intended to at the outset. "Stretching" is especially problematic as small changes in the mixture of policy elements over such a time period can create a situation where the elements can fail to be mutually supportive, incorporating contradictory goals or instruments

\footnotetext{
${ }^{8}$ And they are also interested in related subjects such as how policy experiments can help reveal the possibilities of redesign (Hoffman, 2011) or how building temporal properties into tool mixes- "adaptive policy-making" (Swanson et al., 2010) - can make designs more flexible or resistant to shifting conditions (Haasnoot, Kwakkel, Walker, \& ter Maat, 2013; Walker, Marchau, \& Swanson, 2010).
} 
whose combination create perverse incentives that frustrate initial policy goals. These problems when identified set the stage for further rounds of tinkering and layering that may make them even worse (Feindt \& Flynn, 2009).

Both stretching and poor patching efforts hence can create a particular form of "tense layering" (Kay, 2007) which occurs when repeated bouts of layering lead to incoherence amongst goals and inconsistency with respect to the instruments and settings used in a policy area. Inconsistencies arise where the means work at cross-purposes, "providing simultaneous incentives and disincentives towards the attainment of stated goals" (Kern \& Howlett, 2009, p. 6). And incongruence occurs when an otherwise consistent mix of instruments fails to support the goals. Stretching is problematic as a design process since the addition of new goals or objectives increases the risk of incoherence, while the introduction of policy instruments through poor patching, for example, when a market orientation is introduced into an instrument set that has been based on a regulatory approach (Howlett \& Rayner, 2007) is also unlikely to work well.

Using the case of British food policy, Feindt and Flynn (2009), for example, describe a situation of institutional stretching where "concerns about food supply and high productivity have been overlaid with policies addressing food safety, the environment, quality foods, obesity and climate change" (p. 386). As a result, they argue, "the resulting tensions...create opportunities for more new ideas and actors to move in, fuelled by a plurality of social constructions of food. Also, each new layer re-adjusts the power balance and necessitates reinterpretations of older policies" (p. 386).

Layering and patching thus have two sides. On the one hand negative stretching or destructive layering exacerbates tensions between regime elements and more politicized or less instrumental forms of policymaking and outcomes. However layering can also have a positive side and help ameliorate or reduce tensions through "smart" patching. Stretching and poor patching are thus design practices which exist at the breakpoint between design and non-design activities of government. Both these processes fall between the "pure" design and "pure" non-design ends of the spectrum of design processes suggested in Table 1.

As Figure 1 shows, these forms of policy-oriented formulation processes move from highly intentional and instrumental replacement efforts to those which are more partial and less intentional such as "smart" patching and ultimately to those which involve poor design such as "stretching" and poor or tense layering. In cases such as these layering introduces progressively more severe inconsistencies and incongruences and tensions between layers and policy-making and formulation may begin to take on an increasingly political complexion as the original logic and causality of a mix recedes into dim memory.

Non-design types also vary in the same way as partisan and ideological, religious or other criteria cloud, crowd out or replace instrumental design intentionality. Non-design mechanisms, as highlighted above, include activities such as alternative generation by bargaining or log-rolling, through corruption or cooptation efforts or through other faith-based or purely electoral calculations which are not instrumental in the same sense as are design efforts. In such contexts the ability of policy goals to be met or the ability of means to achieve them are of secondary concern to other concerns such as ideological purity or the need to retain or augment legislative or electoral support or other similar kinds of coalition behaviour.

These too, however, can also be done well or poorly and are affected by contextual barriers but are not "design" activities in the intentional instrumental public problem-solving sense set out above. That is, maximizing the return from a bargain or the returns from corruption, for example, also depends on the context, situation and expertise of actors but does not involve the same kinds of appraisal activities and competences or intentions on the part of governments as does policy design work.

Non-design processes have been studied extensively in the political science literature but less systematically in the policy sciences (Frye, Reuter, \& Szakonyi, 2012; Gans-Morse, Mazzuca, \& Nichter, 2014; Goodin, 1980; Saward, 1992) despite their prevalence and importance in many areas. While it is not necessary to include them in a spectrum of design work, they can be appended to a spectrum of formulation types by moving from those types of non-design work which are compatible with at least some aspects of instrumental design activities-such as bargaining among affected interests over elements of otherwise carefully designed policy alternatives-to those-such as pure electoral opportunism or corruption-where party, leader or individual self-interest replace policy instrumentalism altogether (see Figure 2).

\section{$\left.\begin{array}{c}\text { Packaging } \\ (\text { "Pure Design") }\end{array}\right)$ Patching Drift $>$ Stretching $>\begin{gathered}\text { Tense } \\ \text { Layering }\end{gathered}>$ Non-Design}

Figure 1. A spectrum of design processes. 
Extent of Design Capability

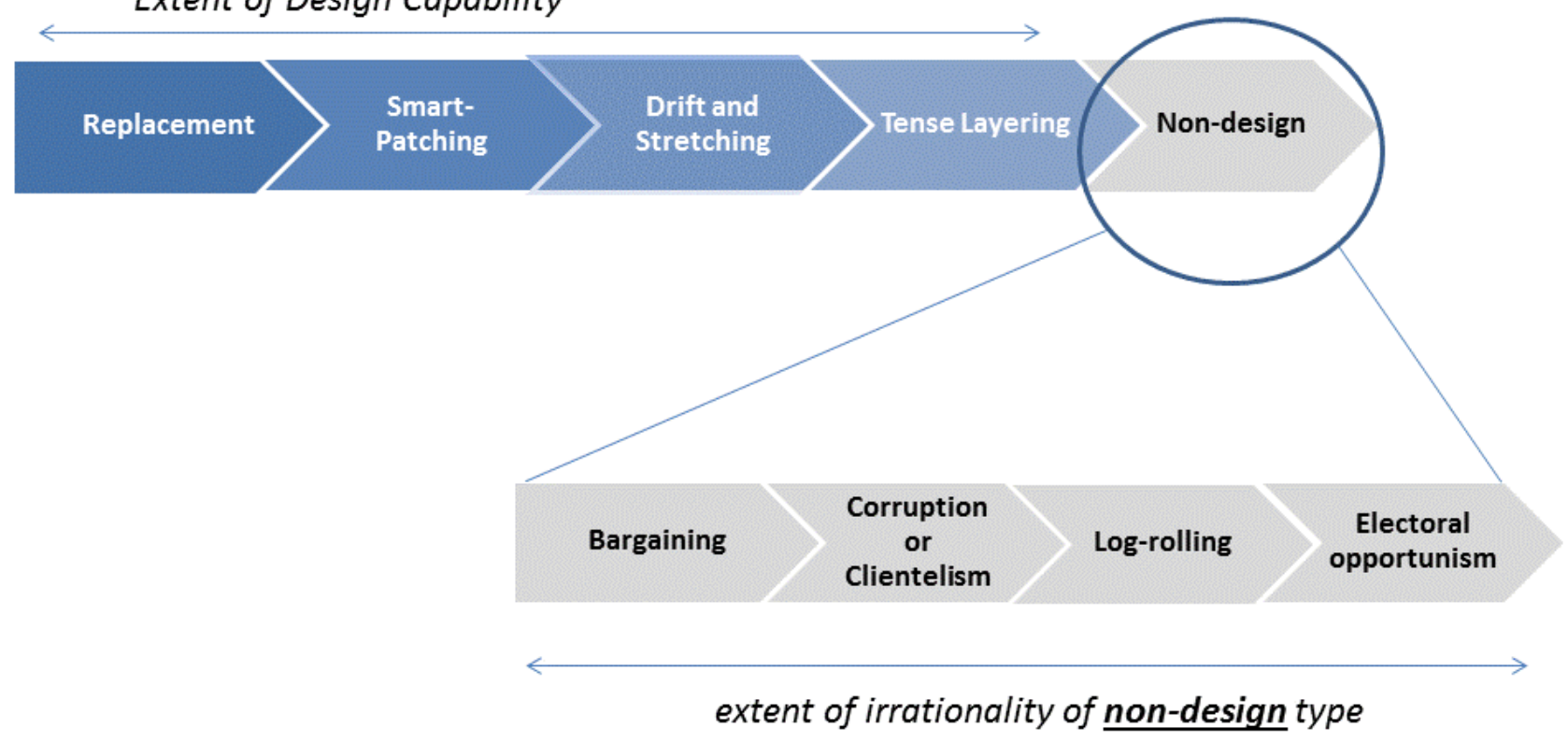

Figure 2. A spectrum of design and non-design processes.

\section{Conclusion: Distinguishing Design from Non-Design-Based Formulation}

Transforming policy ambitions into practice is a complex process and intentionally creating the best possible arrangement of policy elements is not always the first item on a government's mind, nor necessarily within its reach. Many noble efforts of policy formulators have failed due to poor design capacity or the inability or lack of desire on the part of decision-makers to alter elements of existing policies or create new ones in a logical, instrumental, fashion (Cohn, 2004; Howlett, 2012). These experiences have led to a greater awareness of the various obstacles that can present themselves to policy design efforts and have gradually fueled a desire for better understanding the unique characteristics of policy formulation processes and the spaces and contexts in which design efforts are embedded.

As the discussion here has shown, both design and non-design processes vary along several important dimensions. For design situations - that is those characterized by a government desire to systematically match ends and means in the attainment of public policy goals, the processes vary according to the nature of the resources available for design purposes and the constraints imposed by policy legacies. The former often determine the quality of the design effort and impact the design itself while the latter generate contexts in which processes such as patching and stretching unfold. In a more non-design world where the intention to instrumentally design is lacking, constraints on outcomes also exist as do different processes which vary in their distance from the design ideal of public value and service and improving the public good through better information and knowledge utilization and improved management efforts (Holmberg \& Rothstein, 2012; Rotberg, 2014).

Students of policy design must be aware of these different formulation contexts, processes and outcomes and be able to properly and accurately assess the situations governments are in or want to be in while developing policy options and when making recommendations and providing advice to governments. More systematic study of the formulation contexts and processes set out above can help move this area of policy design studies forward.

\section{Acknowledgements}

The authors would like to thank the participants at the Panel on "Issues in Policy Formulation Theory \& Practice" at the IPSA $23^{\text {rd }}$ World Congress of Political Science held in Montreal, PQ Canada on July 19-24, 2014, for their feedback on an early draft of this paper.

\section{Conflict of Interests}

The authors declare no conflict of interests.

\section{References}

Ackerman, B. (1981). Clean Coal/Dirty Air: Or How the Clean Air Act Became a Multibillion-Dollar Bail-Out for High-Sulfur Coal Producers (Vol. 23). New Haven: Yale University Press.

Arts, B., \& Van Tatenhove, J. (2004). Policy and power: 
A conceptual framework between the "old" and "new" policy idioms. Policy Sciences, 37, 339-356.

Azuela, G. E., \& Barroso, L. A. (2012). Design and Performance of Policy Instruments to Promote the Development of Renewable Energy: Emerging Experience in Selected Developing Countries. Washington, D.C.: World Bank Publications.

Bardach, E. (1980). Implementation studies and the study of implements. Paper presented to the American Political Science Association.

Barnett, C. K., \& Shore, B. (2009). Reinventing program design: Challenges in leading sustainable institutional change. Leadership \& Organization, 30(1), 16-35.

Beland, D. (2007). Ideas and institutional change in social security: Conversion, layering, and policy drift. Social Science Quarterly, 88(1), 20-38.

Beland, D., \& Hacker, J. (2004). Ideas, private institutions, and American welfare state "exceptionalism". International Journal of Social Welfare, 13(1), 42-54.

Bendor, J., Kumar, S., \& Siegel, D. A. (2009). Satisficing: A "pretty good" heuristic. The B.E. Journal of Theoretical Economics, 9(1). doi:10.2202/1935-1704.1478.

Bhatta, G. (2002). Evidence-based analysis and the work of policy shops. Australian Journal of Public Administration, 61(3), 98-105.

Blonz, J. A., Vajjhala, S. P., \& Safirova, E. (2008). Growing Complexities: A Cross-Sector Review of U.S. Biofuels Policies and Their Interactions. Washington, D.C.: Resources for the Future.

Bobrow, D. B., \& Dryzek, J. S. (1987). Policy Analysis by Design. Pittsburgh: University of Pittsburgh Press.

Bobrow, D. (2006). Policy Design: Ubiquitous, Necessary and Difficult. In B. G. Peters \& J. Pierre (Eds.), Handbook of Public Policy (pp. 75-96). Beverly Hills: Sage Publications.

Bode, I. (2006). Disorganized welfare mixes: Voluntary agencies and new governance regimes in Western Europe. Journal of European Social Policy, 16(4), 346-359.

Bressers, H., \& Honigh, M. (1986). A comparative approach to the explanation of policy effects. International Social Science Journal, 108, 267-288.

Bressers, H., \& Klok, P. J. (1988). Fundamentals for a theory of policy instruments. International Journal of Social Economics, 15(3-4), 22-41.

Buckman, G., \& Diesendorf, M. (2010). Design limitations in Australian renewable electricity policies. Energy Policy, 38(7), 3365-3376.

Carter, P. (2012). Policy as palimpsest. Policy \& Politics, 40(3), 423-443.

Clemens, E. S., \& Cook, J. M. (1999). Politics and institutionalism: Explaining durability and change. Annual Review of Sociology, 25, 441-466.

Cohen, M. D., March, J. G., \& Olsen, J. P. (1979). People, Problems, Solutions and the Ambiguity of Relevance. In Ambiguity and Choice in Organizations (pp. 24-37). Bergen: Universitetsforlaget.
Cohn, D. (2004). The best of intentions, potentially harmful policies: A comparative study of scholarly complexity and failure. Journal of Comparative Policy Analysis, 6(1), 39-56.

Colebatch, H. K. (1998). Policy. Minneapolis: University of Minnesota Press.

Dahl, R. A., \& Lindblom, C. E. (1953). Politics, Economics and Welfare: Planning and Politico-economic Systems Resolved into Basic Social Processes. New York: Harper and Row.

Davies, P. (2004). Is Evidence-Based Government Possible? London: Cabinet Office.

De Bruijn, J. A., \& ten Heuvelhof, E. F. (1997). Instruments for Network Management. In W. J. M. Kickert, E. H. Klijn, \& J. F. M. Koppenjan (Eds.), Managing Complex Networks: Strategies for the Public Sector. Beverly Hills: Sage Publications.

Del Río, P. (2010). Analysing the interactions between renewable energy promotion and energy efficiency support schemes: The impact of different instruments and design elements. Energy Policy, 38(9), 4978-4989.

Del Rio, P., \& Howlett, M. P. (2013). Beyond the "tinbergen rule" in policy design: Matching tools and goals in policy portfolios. Social Science Research Network. Retrieved from http://papers.ssrn.com/abstract=224 7238

deLeon, P. (1988). The contextual burdens of policy design. Policy Studies Journal, 17(2), 297-309.

Doremus, H. (2003). A policy portfolio approach to biodiversity protection on private lands. Environmental Science \& Policy, 6, 217-232.

Dror, Y. (1964). Muddling through: "Science" or inertia. Public Administration Review, 24(3), 154-157.

Dryzek, J. (1983). Don't toss coins in garbage cans: A prologue to policy design. Journal of Public Policy, 3(4), 345-367.

Dryzek, J. S., \& Ripley, B. (1988). The ambitions of policy design. Policy Studies Review, 7(4), 705-719.

Dunlop, C. A. (2009). The temporal dimension of knowledge and the limits of policy appraisal: Biofuels policy in the UK. Policy Sciences, 43(4), 343-363. doi:10.1007/s11077-009-9101-7.

Eijlander, P. (2005). Possibilities and constraints in the use of self-regulation and co-regulation in legislative policy: Experiences in the Netherlands-lessons to be learned for the EU. Electronic Journal of Comparative Law, 9(1), 1-8.

Eliadis, F. P., Hill, M. M., \& Howlett, M. (Eds.) (2005). Designing Government: From Instruments To Governance. Montreal: McGill Queens University Press.

Feindt, P., \& Flynn, A. (2009). Policy stretching and institutional layering: british food policy between security, safety, quality, health and climate change. British Politics, 4(3), 386-414.

Franchino, F., \& Hoyland, B. (2009). Legislative involvement in parliamentary systems: Opportunities, 
conflict and institutional constraints. American Political Science Review, 103(4), 607-621.

Frye, T., Reuter, O. J., \& Szakonyi, D. (2012). Political machines at work: voter mobilization and electoral subversion in the workplace. Social Science Research Network. Retrieved from http://papers. ssrn.com/abstract $=2110201$

Gans-Morse, J., Mazzuca, S., \& Nichter, S. (2014). Varieties of clientelism: Machine politics during elections. American Journal of Political Science, 58(2), 415-432. doi:10.1111/ajps.12058.

Gero, J. S. (1990). Design Prototypes: A Knowledge Representation Schema for Design. Al Magazine, 11(4), 26-36.

Gilabert, P., \& Lawford-Smith, H. (2012). Political feasibility: A conceptual exploration. Political Studies, 60(4), 809-825.

Goggin, M. L., Bowman, A. O. M., Lester, J. P., \& O’Toole, L. J. (1990). Implementation Theory and Practice: Toward A Third Generation. Glenview: Scott Foresman/Little Brown.

Goldmann, K. (2005). Appropriateness and consequences: The logic of neo-institutionalism. Governance, 18(1), 35-52.

Goodin, R. E. (1980). Manipulatory Politics. New Haven: Yale University Press.

Grabosky, P. N. (1994). Green markets: Environmental regulation by the private sector. Law and Policy, 16(4), 419-448.

Greenstone, M. (2001). The Impacts of Environmental Regulations on Industrial Activity: Evidence from the 1970 \& 1977 Clean Air Act Amendments and the Census of Manufactures (No. w8484). Cambridge: National Bureau of Economic Research.

Gunningham, N., Grabosky, P., \& Sinclair, N. (1998). Smart Regulation: Designing Environmental Policy. Oxford: Oxford University Press.

Gunningham, N., \& Sinclair, D. (1999a). New generation environmental policy: Environmental management systems and regulatory reform. Melbourne University Law Review, 22(3), 592-616.

Gunningham, N., \& Sinclair, D. (1999b). Regulatory pluralism: Designing policy mixes for environmental protection. Law Policy, 21(1), 49-76.

Haasnoot, M., Kwakkel, J. H., Walker, W. E., \& ter Maat, J. (2013). Dynamic adaptive policy pathways: a method for crafting robust decisions for a deeply uncertain world. Global Environmental Change, 23(2), 485-498.

Hacker, J. (2004). Privatizing risk without privatizing the welfare state: The hidden politics of social policy retrenchment in the United States. American Political Science Review, 98(2), 243-260.

Hillier, B., \& Leaman, A. (1974). How is design possible: A sketch for a theory. DMG-DRS Journal: Design Research and Methods, 8(1), 40-50.

Hillier, B., Musgrave, J., \& O’Sullivan, P. (1972).
Knowledge and Design. In W. J. Mitchell (Ed.), Environmental Design: Research and Practice. Los Angeles: University of California, Los Angeles.

Hippes, G. (1988). New instruments for environmental policy: A perspective. International Journal of Social Economics, 15(3-4), 42-51.

Hoffmann, M. J. (2011). Climate Governance at the Crossroads: Experimenting with a Global Response after Kyoto. Oxford: Oxford University Press.

Holmberg, S., \& Rothstein, B. (2012). Good Government: The Relevance of Political Science. Cheltenham and Northampton: Edward Elgar.

Hood, C. (1986). The Tools of Government. Chatham: Chatham House Publishers.

Hood, C. (2007). Intellectual obsolescence and intellectual makeovers: Reflections on the tools of government after two decades. Governance, 20(1), 127-144.

Hood, C. (2010). The Blame Game: Spin, Bureaucracy, and Self-Preservation in Government. Princeton: Princeton University Press.

Hood, C., \&. Margetts, H. Z. (2007). The Tools of Government in the Digital Age. Basingstoke: Palgrave Macmillan.

Hou, Y., \& Brewer, G. (2010). Substitution and supplementation between co-functional policy instruments: Evidence from state budget stabilization practices. Public Administration Review, 70(6), 914-924.

Howlett, M. (1991). Policy instruments, policy styles, and policy implementation: National approaches to theories of instrument choice. Policy Studies Journal, 19(2), 1-21.

Howlett, M. (2000). Managing the "hollow state": Procedural policy instruments and modern governance. Canadian Public Administration, 43(4), 412-431.

Howlett, M. (2004). Beyond good and evil in policy implementation: Instrument mixes, implementation styles and second generation theories of policy instrument choice. Policy \& Society, 23(2), 1-17.

Howlett, M. (2009a). Governance modes, policy regimes and operational plans: A multi-level nested model of policy instrument choice and policy design. Policy Sciences, 42, 73-89.

Howlett, M. (2009b). Policy analytical capacity and evidence-based policy-making: Lessons from canada. Canadian Public Administration, 52(2), 153-175.

Howlett, M. (2011). Designing Public Policies: Principles and Instruments. New York: Routledge.

Howlett, M. (2012). The lessons of failure: Learning and blame avoidance in public policy-making. International Political Science Review, 33(5), 539-555.

Howlett, M. (2014). Policy Design: What, Who, How and Why? In C. Halpern, P. Lascoumes, \& P. Le Gales (Eds.), L'Instrumentation et Ses Effets. Paris: Presses de Sciences Po.

Howlett, M. (2014b). From the "old" to the "new" policy design: Beyond globalization and collaborative 
governance. Policy Sciences, forthcoming.

Howlett, M., \& Lejano, R. (2013). Tales from the crypt: The rise and fall (and re-birth?) of policy design studies. Administration \& Society, 45(3), 356-380.

Howlett, M., Mukherjee, I., \& Woo, J. J. (2014). The new design orientation in policy formulation research: From tools to toolkits in policy instrument studies. Policy and Politics, forthcoming.

Howlett, M., \& Ramesh, M. (1993). Patterns of policy instrument choice: Policy styles, policy learning and the privatization experience. Policy Studies Review, 12(1), 3-24.

Howlett, M., Ramesh, M., \& Perl, A. (2009). Studying Public Policy. Canada: Oxford University Press Canada.

Howlett, M., \& Rayner, J. (1995). Do ideas matter? Policy subsystem configurations and the continuing conflict over Canadian forest policy. Canadian Public Administration, 38(3), 382-410.

Howlett, M., \& Rayner, J. (2007). Design principles for policy mixes: Cohesion and coherence in "new governance arrangements". Policy and Society, 26(4), 1-18.

Howlett, M., \& Rayner, J. (2013). Patching vs packaging in policy formulation: Assessing policy portfolio design. Politics and Governance, 1(2), 170-182.

Howlett, M., Tan, S. L., Migone, A., Wellstead, A., \& Evans, B. (2014). The distribution of analytical techniques in policy advisory systems: Policy formulation and the tools of policy appraisal. Public Policy and Administration, 29(4), 271-291. doi:10.1177/ 0952076714524810.

Ingram, H., \& Schneider, A. (1990). Improving implementation through framing smarter statutes. Journal of Public Policy, 10(1), 67-88.

Jordan, A., Benson, D., Wurzel, R., \& Zito, A. (2011). Policy Instruments in Practice. In J. S. Dryzek, R. B. Norgaard, \& D. Schlosberg (Eds.), Oxford Handbook of Climate Change and Society (pp. 536-549). Oxford: Oxford University Press.

Jordan, A., Benson, D., Zito, A., Wurzel, R. (2012). Environmental Policy: Governing by Multiple Policy Instruments? In J. J. Richardson (Ed.), Constructing a Policy State? Policy Dynamics in the EU. Oxford: Oxford University Press.

Junginger, S. (2013). Design and innovation in the public sector: Matters of design in policy-making and policy implementation. $10^{\text {th }}$ European Academy of Design Conference-Crafting the Future.

Kay, A. (2007). Tense layering and synthetic policy paradigms: The politics of health insurance in Australia. Australian Journal of Political Science, 42(4), 579-591.

Kern, F., \& Howlett, M. (2009). Implementing transition management as policy reforms: A case study of the Dutch energy sector. Policy Science, 42(4), 391-408.

Keyes, J. M. (1996). Power tools: The form and function of legal instruments for government action. Cana- dian Journal of Administrative Law and Practice, 10, 133-174.

Kingdon, J. W. (1984). Agendas, Alternatives, and Public Policies. Boston: Little Brown.

Kirschen, E. S., Benard, J., Besters, H., Blackaby, F., Eckstein, O., Faaland, J., Hartog, F., Morissens, L., \& Tosco, E. (1964). Economic Policy in Our Time. Chicago: Rand McNally.

Landry, R., Varone, F., \& Goggin, M. L. (1998). The determinants of policy design: The state of the theoretical literature. Paper presented to the Midwest Political Science Association, Chicago.

Lascoumes, P., \& Le Gales, P. (2007). Introduction: Understanding public policy through its instruments From the nature of instruments to the sociology of public policy instrumentation. Governance, 20(1), 121.

Lasswell, H. (1954). Key Symbols, Signs and Icons. In L. Bryson, L. Finkelstein, R. M. Maclver, \& Richard McKean (Eds.), Symbols and Values: An Initial Study (pp. 77-94). New York: Harper \& Bros.

Lasswell, H. (1958). Politics: Who Gets What, When, How. New York: Meridian.

Lasswell, H. D., \& Lerner, D. (1951). The Policy Orientation. In The Policy Sciences: Recent Developments in Scope and Method (pp. 3-15). Stanford: Stanford University Press.

Libecap, G. D. (2005). State Regulations of OpenAccess, Common-Pool Resources. In C. Menard \& M. M Shirley (Eds.), Handbook of New Institutional Economics (pp. 545-572). Dordrecht: Springer.

Lindblom, C. E. (1959). The science of muddling through. Public Administration Review, 19(2), 79-88.

Linder, S. H., \& Peters, B. G. (1984). From social theory to policy design. Journal of Public Policy, 4(3), 237-259.

Linder, S. H., \& Peters, B. G. (1988). The analysis of design or the design of analysis? Policy Studies Review, 7(4), 738-750.

Linder, S. H., \& Peters, B. G. (1990a). Policy formulation and the challenge of conscious design. Evaluation and Program Planning, 13, 303-311.

Linder, S. H., \& Peters, B. G. (1990b). Research Perspectives on the Design of Public Policy: Implementation, Formulation, and Design. In D. J. Palumbo \& D. J. Calisto (Eds.), Implementation and the Policy Process: Opening up the Black Box (pp. 51-66). New York: Greenwood Press.

Linder, S. H., \& Peters, B. G. (1990c). The Design of Instruments for Public Policy. In S. S. Nagel (Ed.), Policy Theory and Policy Evaluation: Concepts, Knowledge, Causes, and Norms (pp. 103-119). New York: Greenwood Press.

Linder, S. H., \& Peters, B. G. (1990d). An institutional approach to the theory of policy-making: The role of guidance mechanisms in policy formulation. Journal of Theoretical Politics, 2(1), 59-83.

Linder, S. H., \& Peters, B. G. (1991). The logic of public 
policy design: Linking policy actors and plausible instruments. Knowledge, Technology \& Policy, 4(1), 125-151.

Locke, W. (2009). Reconnecting the research-policypractice nexus in higher education: "Evidence-based policy" in practice in national and international contexts. Higher Education Policy, 22, 119-140.

Lowi, T. J. (1966). Distribution, Regulation, Redistribution: The Functions of Government. In R. B. Ripley (Ed.), Public Policies and Their Politics: Techniques of Government Control (pp. 27-40). New York: W.W. Norton.

Lowi, T. J. (1972). Four systems of policy, politics and choice. Public Administration Review, 32(4), 298-310.

Lowi, T. J. (1985). The State in Politics: The Relation between Policy and Administration. In R. G. Noll (Ed.), Regulatory Policy and the Social Sciences (pp. 67105). Berkeley: University of California Press.

Majone, G. (1975). On the notion of political feasibility. European Journal of Political Research, 3(2), 259274.

Majone, G. (1976). Choice among policy instruments for pollution control. Policy Analysis, 2(4), 589-613.

March, J. G., \& Olsen, J. P. (2004). The logic of appropriateness. Martin Rein, Michael Moran and Robert E. Goodin (eds.), Handbook of Public Policy, Oxford University Press.

May, P. (2003). Policy Design and Implementation. In B. Guy Peters \& J. Pierre (Eds.), Handbook of Public Administration (pp. 223-233). Beverly Hills: Sage Publications.

Mayntz, R. (1979). Public bureaucracies and policy implementation. International Social Science Journal, 31(4), 633-645.

Meijers, E. (2004). Policy Integration: A Literature Review. In D. Stead, H. Geerlings \& E. Meijers (Eds.), Policy Integration in Practice: The Integration of Land Use Planning, Transport and Environmental Policy-Making in Denmark, England and Germany (pp. 9-24). Delft: Delft University Press.

Mintrom, M. (2007). The Policy Analysis Movement. In L. Dobuzinskis, M. Howlett, \& D. Laycock (Eds.), Policy Analysis in Canada: The State of the Art (pp. 7184). Toronto: University of Toronto Press.

Mondou, M., \& Montpetit, E. (2010). Policy styles and degenerative politics: Poverty policy designs in Newfoundland and Quebec. Policy Studies Journal, 38(4), 703-722. doi:10.1111/j.1541-0072.2010.00380.x.

Montpetit, E. (2003). Misplaced Distrust: Policy Networks and the Environment in France, the United States, and Canada. Vancouver: UBC Press.

Moseley, A., \& Tierney, S. (2004). Evidence-based practice in the real world. Evidence \& Policy, 1(1), 113119.

Nutley, S. M., Walter, I., \& Davies, H. T. O. (2007). Using Evidence: How Research Can Inform Public Services. Bristol: Policy Press.
O'Toole, L. J. (2000). Research on policy implementation: Assessment and prospects. Journal of Public Administration Research and Theory, 10(2), 263288.

Oliphant, S., \& Howlett, M. (2010). Assessing policy analytical capacity: Comparative insights from a study of the Canadian environmental policy advice system. Journal of Comparative Policy Analysis: Research and Practice, 12(4), 439.

Orren, K., \& Skowronek, S. (1998). Regimes and regime building in American government: A review of literature on the 1940s. Political Science Quarterly, 113(4), 689-702.

Parsons, W. (1995). Public Policy: An Introduction to the Theory and Practice of Policy Analysis. Aldershot Cheltenham: Edward Elgar.

Parsons, W. (2001). Modernising policy-making for the twenty first century: The professional model. Public Policy and Administration, 16(3), 93-110.

Peters, B. G., \& Pierre, J. (1998). Governance without government? Rethinking public administration. Journal of Public Administration Research and Theo$r y, 8(2), 223-244$.

Radaelli, C. M., \& Dunlop, C. A. (2013). Learning in the European Union: Theoretical lenses and metatheory. Journal of European Public Policy, 20(6), 923-940. doi:10.1080/13501763.2013.781832.

Rayner, J. (2013). On smart layering as policy design: Tackling the biofuels policy mess in Canada and the United Kingdom. Policy Sciences, forthcoming.

Rayner, J., Howlett, M., Wilson, J., Cashore, B., \& Hoberg, G. (2001). Privileging the sub-sector: Critical sub-sectors and sectoral relationships in forest policy-making. Forest Policy and Economics, 2(3), 319-332.

Roch, C., Pitts, D., \& Navarro, I. (2010). Representative bureaucracy and policy tools: Ethnicity, student discipline, and representation in public schools. Administration \& Society, 42(1), 38-65.

Rotberg, R. I. (2014). Good governance means performance and results. Governance, 27(3), 511-518. doi:10.1111/gove.12084.

Sager, F., \& Rielle, Y. (2013). Sorting through the garbage can: Under what conditions do governments adopt policy programs? Policy Sciences, 46(1), 1-21. doi:10.1007/s11077-012-9165-7.

Salamon, L. (1981). Rethinking public management: Third party government and the changing forms of government action. Public Policy, 29(3), 255-275.

Salamon, L. M. (1989). The Tools Approach: Basic Analytics. In L. S. Salamon \& M. S. Lund (Eds.), Beyond Privatization: The Tools of Government Action (pp. 23-50). Washington, D.C.: Urban Institute.

Salamon, L. M. (2002). The Tools of Government: A Guide to the New Governance. New York: Oxford University Press.

Saward, M. (1992). Co-Optive Politics and State Legiti- 
macy. Aldershot: Dartmouth.

Schmalensee, R., Joskow, P. L., Ellerman, A. D., Montero, J. P., \& Bailey, E. M. (1998). An interim evaluation of sulfur dioxide emissions trading. The Journal of Economic Perspectives, 12(3), 53-68.

Schneider, A. L., \& Ingram, H. (1990a). Policy Design: Elements, Premises and Strategies. In S. S. Nagel (Ed.), Policy Theory and Policy Evaluation: Concepts, Knowledge, Causes and Norms (pp. 77-102). New York: Greenwood.

Schneider, A. L., \& Ingram, H. (1990b). Behavioural assumptions of policy tools. Journal of Politics, 52(2), 511-529.

Schneider, A., \& Ingram, H. (1994). Social constructions and policy design: Implications for public administration. Research in Public Administration, 3, 137173.

Schneider, A. L., \& Ingram, H. (1997). Policy Design for Democracy. Lawrence: University Press of Kansas.

Schön, D. A. (1988). Designing: Rules, types and words. Design Studies, 9(3), 181-190.

Schön, D. A. (1992). Designing as reflective conversation with the materials of a design situation. Knowledge-Based Systems, 5(1), 3-14.

Sidney, M. S. (2007). Policy Formulation: Design and Tools. In F. Fischer, G. J. Miller, \& M. S. Sidney (Eds.), Handbook of Public Policy Analysis: Theory, Politics and Methods (pp. 79-87). New Brunswick, N. J.: CRC Taylor \& Francis.

Stead, D., \& Meijers, E. (2004). Policy integration in practice: Some experiences of integrating transport, landuse planning and environmental policies in local government. 2004 Berlin Conference on the Human Dimensions of Global Environmental Change: Greening of Policies-Interlinkages and Policy Integration.

Sterner, T. (2003). Policy Instruments for Environmental and Natural Resource Management. Washington, D.C.: Resource for the Future Press.

Stokey, E., \& Zeckhauser, R. (1978). A Primer for Policy Analysis. New York: Norton.

Stone, D. A. (1988). Policy Paradox and Political Reason. Glenview: Scott, Foresman.

Swanson, D., Barg, S., Tyler, S., Venema, H., Tomar, S., Bhadwal, S., Nair, S., Roy, D., \& Drexhage, J. (2010). Seven tools for creating adaptive policies. Technological Forecasting and Social Change, 77(6), 924939.

Thelen, K., Mahoney, J., \& Rueschemeyer, D. (2003). How Institutions Evolve: Insights from Comparative Historical Analysis. In Comparative Historical Analysis in the Social Sciences (pp. 208-240). Cambridge: Cambridge University Press.

Thelen, K. (2004). How Institutions Evolve: The Political Economy of Skills in Germany, Britain, the United States and Japan. Cambridge: Cambridge University Press.

Timmermans, A., Rothmayr, C., Serduelt, U. \& Varone,
F. (1998). The design of policy instruments: Perspectives and concepts. Paper presented to the Midwest Political Science Association, Chicago.

Tinbergen, J. (1952). On the Theory of Economic Policy. North-Holland Pub. Co.

Torenvlied, R., \& Akkerman, A. (2004). Theory of "soft" policy implementation in multilevel systems with an application to social partnership in the Netherlands. Acta Politica, 39, 31-58.

Torgerson, D. (1985). Contextual orientation in policy analysis: The contribution of Harold D. Lasswell. Policy Sciences, 18, 240-252.

Torgerson, D. (1990). Origins of the policy orientation: The aesthetic dimension in Lasswell's political vision. History of Political Thought, 11, 340-344.

Trebilcock, M., \& Hartle, D. G. (1982). The choice of governing instrument. International Review of Law and Economics, 2, 29-46.

Trebilcock, M. J., \& Prichard, J. R. S. (1983). Crown Corporations: The Calculus of Instrument Choice. In J. R. S. Prichard (Ed.), Crown Corporations in Canada: The Calculus of Instrument Choice (pp.1-50). Toronto: Butterworths.

Tribe, L. H. (1972). Policy science: analysis or ideology? Philosophy and Public Affairs, 2, 66-110.

Tupper, A., \& Doern, G. B. (1981). Public Corporations and Public Policy in Canada. In A. Tupper \& G. B. Doern (Eds.), Public Corporations and Public Policy in Canada (pp. 1-50). Montreal: Institute for Research on Public Policy.

Van der Heijden, J. (2011). Institutional layering: A review of the use of the concept. Politics, 31(1), 9-18.

Vedung, E., Bemelmans-Videc, M. L., \& Rist, R. C. (1997). Policy Instruments: Typologies and Theories. In E. Vedung, M. L. Bemelmans-Videc, \& R. C. Rist (Eds.), Carrots, Sticks and Sermons: Policy Instruments and Their Evaluation (pp. 21-58). New Brunswick: Transaction Publishers.

Walker, W. E., Marchau, V. A. W. J., \& Swanson, D. (2010). Addressing deep uncertainty using adaptive policies: Introduction to Section 2. Technological Forecasting and Social Change, 77(6), 917-923.

Weaver, K. (2009). Target Compliance: The Final Frontier of Policy Implementation. Washington, D.C.: Brookings Institution. Retrieved from http://www. brookings.edu/research/papers/2009/09/30compliance-weaver

Weaver, K. (2010). But Will It Work? Implementation Analysis to Improve Government Performance. Washington, D.C.: Brookings Institution. Retrieved from http://www.brookings.edu/research/papers/ 2010/02/implementation-analysis-weaver

Wildavsky, A. B. (1979). Speaking Truth to Power: The Art and Craft of Policy Analysis. Boston: LittleBrown.

Williams, R. A. (2012). The limits of policy analytical capacity-Canadian financial regulatory reform. In- 
ternational Journal of Public Sector Management, 25(6-7), 455-463.

Wintges, R. (2007). Monitoring and Analysis of Policies and Public Financing Instruments Conducive to Higher Levels of R\&D Investments: The "Policy Mix" Project-Case Study: The Netherlands. Maastricht: UNU-MERIT.
Woodside, K. (1986). Policy instruments and the study of public policy. Canadian Journal of Political Science, 19(4), 775-793.

Yi, H., \& Feiock, R. C. (2012). Policy tool interactions and the adoption of state renewable portfolio standards. Review of Policy Research, 29(2), 193 206.

\section{About the Authors}

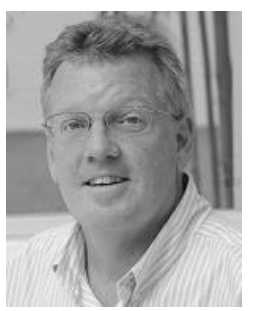

\section{Dr. Michael Howlett}

Michael Howlett is Burnaby Mountain Chair in the Department of Political Science at Simon Fraser University and Yong Pung How Chair Professor in the Lee Kuan Yew School of Public Policy at the National University of Singapore. He specializes in public policy analysis, political economy, and resource and environmental policy. His most recent books are Canadian Public Policy (2013) and The Routledge Handbook of Public Policy (2013).

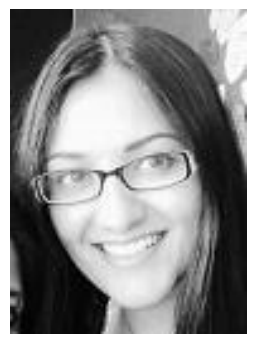

\section{Dr. Ishani Mukherjee}

Ishani Mukherjee is Postdoctoral Fellow at the LKY School of Public Policy, National University of Singapore. She received her PhD in Public Policy from NUS, with a concentration on Environmental Policy. Her research interests combine policy design and policy formulation, with a thematic focus on environmental sustainability, renewable energy and energy efficiency, particularly in Southeast Asia. She has worked previously at the World Bank's Energy practice in Washington, DC, and obtained her BSc (hon) and MSc (hon) in Natural Resources and Environmental Economics from Cornell University. 